\title{
Model By Doing in Learning Official Volley Ball Games
}

\author{
$1^{\text {st }}$ Rosmaini Hasibuan ${ }^{1}, 2^{\text {nd }}$ Sabaruddin Yunis Bangun ${ }^{2}, 3^{\text {rd }}$ Samsuddin Siregar $^{3}, 4^{\text {th }}$ \\ Muhammad Yan Ahady ${ }^{4}$ \\ \{rosmainihasibua@yahoo.com ${ }^{1}$, unisbgn@gmail.com ${ }^{2}$, yanahady66@gmail.com ${ }^{3}$ \}
}

Sports Science Study Program, Universitas Negeri Medan, Indonesia ${ }^{1,2}$, Health and Recreation Physical Education Study Program, Universitas Negeri Medan, Indonesia ${ }^{3,4}$

\begin{abstract}
Based on this problem, a learning model is developed that can improve student competence, especially refereeing material. The model developed in this research is a learning by doing model. The method used in developing the model uses the Borg and Gall method (2007). The subjects used in this students. Data were collected through observations and questionnaires. The data analysis technique uses quantitative analysis techniques with a Liker scale percentage. Based on the results of data analysis obtained from experts related to the feasibility of the by doing learning model for volleyball refereeing material. It can be seen that expert 1 assesses the model by doing from the objective aspect, material aspect and fit aspect of the model to have a percentage level of quality of $90.8 \%$ or very good. Then for expert 2 assessing the model by doing from the objective aspect, material aspect and model fit aspect, it has a quality percentage level of $93.4 \%$ or very good. Thus, it can be stated that the by doing model deserves to be continued for field trials to determine the efficiency and effectiveness of the model.
\end{abstract}

Keywords: Model, by doing, volleyball, refereeing.

\section{Introduction}

The Faculty of Sports Science, State University of Medan is a faculty that aims to graduate students who are competent in the field of physical education, sports and health. Various subjects must be studied by students to achieve these competencies, one of which is volleyball. This course has a credit unit load of semester 2 , meaning that students for 1 semester must take 16 study meetings with lecturers. Various main materials contained in this course, including history, concepts, basic techniques and tactics of volleyball games, game strategies, and refereeing. All these materials are required by students to master it and be able to actualize it in the context of learning and practice.

So far, the forms of learning that students get in volleyball courses are based on the materials provided by their lecturers, namely in the form of textbooks, lecturers and videos, the learning resources are actually good. Regarding how to train student refereeing skills through various practical activities so far, lecturers have done it through procedures; the lecturer explains and demonstrates-students pay attention and demonstrate, then students practice independently. The main problem is that this way of lecturing makes students tend to be slow in mastering the subject matter of volleyball, so that learning objectives in the skill aspect are difficult to achieve. This condition makes it difficult for students to practice their 
abilities in refereeing, of course this is a weakness that must be considered. If left unchecked, it is feared that it will have an impact on students.

In principle, even though practical learning is done online, it is hoped that students can still learn without experiencing obstacles by providing the right academic models, variations and services. Therefore, the researcher wants to "develop a by doing learning model for elearning-based table tennis learning with the hope of improving the skills of the Faculty of Sports Science Unimed students. The intended model is a volleyball refereeing learning model, this model will be developed with the rationale of studying theory, student characteristics and the environment.

Learning by doing is experiential learning that starts from experience. Through these experiences, students will give rise to new perceptions, namely difficulties, errors and inaccuracies. And this will be a parameter for educators in conveying material through four elements, namely stages (1) Do, (2) Observation, (3) Reflection, (4) Application. Do means doing various experiences that can take the form of exercises, simulations and real activities. Observation means the teacher makes observations during the Do period. Furthermore, the teacher does reflection, here the educator injects various corrections, suggestions and improvements to students. After the three stages have been passed, then the students apply or re-do the training model based on the improvements that have been given by the educator.

\section{Theory}

The learning model is one of the important aspects for lecturers to master in carrying out their duties, in order to provide quality learning services, both in practical learning and in classical learning. Regarding the definition of a learning model, the model is defined as a form of accurate representation as an actual process that allows a person or group of people to try to act on the model [1]. Then, another opinion of the learning model is a conceptual framework that describes procedures systematically in organizing learning experiences to achieve certain learning goals and serves as a guide for learning designers and teachers in planning and implementing learning activities [2]. The table tennis course is a practical course that aims to provide educational services to students so that they can understand the concept of teaching table tennis and optimize basic table tennis technical skills [3]. In achieving this goal, the role of the learning model is something important. Determining the right learning model is of course adapted to the learning objectives, adapted to the characteristics of students and the basic motion elements of the sport of table tennis.

Do, Observation, Reflection, and Apply is a step model developed in the concept of learning by doing [4]. The four dimensions are a unified learning activity based on learning by doing and carried out systematically to achieve learning objectives. (1) Do means to do, here students do real or experimental practices, exercise simulations, real activities according to their abilities without blaming students. There are two sources of student learning, namely from lecturers and places/clubs for coaching table tennis practice (2) Observation means observing, here the lecturer observes the development of children's practice virtually by using observation instruments. Through this observation, information on the strengths and weaknesses of the students will be collected. Then (3) reflective activities means strengthening in depth the results of observations to find a way out of weaknesses, difficulties that students still face after reflection, then students return (4) Application means returning to practice again. This step of learning by doing is sourced from experience learning, namely experience- 
based learning. Learning that departs from an experience is a way that can stimulate students to seriously participate in the teaching and learning process [5].

Based on the explanation above, Do, Observation, Reflection, and Apply are learning patterns that are considered by researchers in accordance with the principles of teaching sports practice materials. Because the concept of this learning model emphasizes a lot of repetition, while in learning the practice of sports there is the principle of continuity, that the more correct movements are repeated, the faster one's skills will mature.

\section{Result and Discussion}

The learning model developed is a by doing table tennis learning model with the DORA principle based on e-learning. The basis for developing this model is the characteristics of students, the characteristics of the material and the home environment. It is hoped that through this model learning is more attractive and educative. Attractive because this model is designed with activities that are rich in motion, it will make students more active in moving. Educational because this model has the aim of helping students to have an active and independent behavior and improve their own skills. The steps for implementing the model can be seen in the following table.

Table 1. Learning Model Sintax by Doing

\begin{tabular}{|c|c|c|c|}
\hline Stage & Activity & Stage & Activity \\
\hline \multirow{5}{*}{$\begin{array}{l}\text { I. Simulation \& } \\
\text { observation }\end{array}$} & Information mapping & \multirow[t]{5}{*}{ II. Reflecting } & Preparing the Reflection Sheet \\
\hline & $\begin{array}{l}\text { Collecting } \\
\text { information }\end{array}$ & & Giving identity \\
\hline & Analysis information & & Expressing All Forms of Expression \\
\hline & Preparation & & $\begin{array}{l}\text { Freedom of Expression Both Negative } \\
\text { and Positive }\end{array}$ \\
\hline & Implementation & & $\begin{array}{l}\text { Expressions of Aspirations and } \\
\text { Suggestions for Follow Up Information }\end{array}$ \\
\hline & & \multirow[t]{6}{*}{ III. Applying } & Submission of Learning Objectives \\
\hline & & & Generating Motivation \\
\hline & & & Organizing Group \\
\hline & & & $\begin{array}{l}\text { Information Presentation } \\
\text { (Demonstration) }\end{array}$ \\
\hline & & & Guiding Group \\
\hline & & & Implementation Assessment \\
\hline
\end{tabular}

The developed model is then tested by experts to see if the model is feasible or whether this model can be used in volleyball refereeing lessons. Experts were given a questionnaire as an instrument to see the appropriateness of the model. The results of the questionnaire from the experts are illustrated in the following graph. 


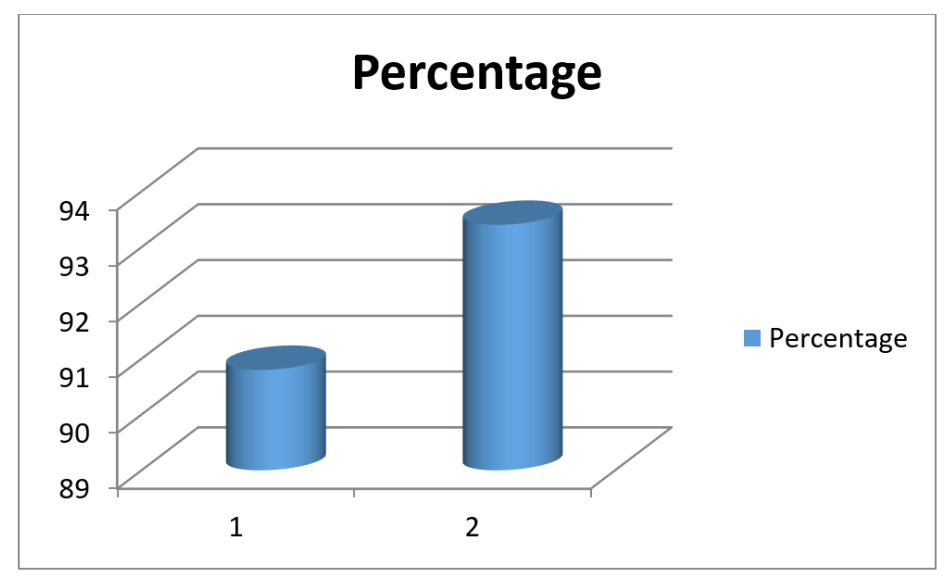

Fig. 1. Percentage of expert judgment on the developed model.

Based on the graph above, it can be explained that expert 1 gave an assessment of the by doing learning model of $90.8 \%$ and expert 2 of $93.4 \%$. The percentage is categorized as very good [6]. This percentage is categorized as very good. It can be interpreted that the by doing learning model is believed to be suitable for use in volleyball refereeing lessons. The by doing model is designed to achieve learning objectives, the systematic application of this model has a goal not only to improve students' knowledge and skills in refereeing material, but also this model can develop critical thinking, communication and collaboration [7]. Conceptually, this model has been feasible, for that this model needs to be tested in the field [8] so that practically this model can be used in learning.

\section{Conclusion}

Research on the development of the model by doing is carried out from step one to step 4 of the Borg and Gall model. Thus, the results of this study need to be followed up with empirical tests to obtain the practical feasibility of the model. For empirical tests, researchers will continue, so that the research has effective results.

\section{References}

[1] Suprijono A. Model-Model Pembelajaran Emansipatoris. Yogyakarta: Pustaka Pelajar; 2016.

[2] Malawi I, Kadarwati A. Pembelajaran Tematik (Konsep dan Aplikasi). Magetan: CV Ae Media Grafika; 2017.

[3] Siregar S. Efektivitas Model Pembelajaran Berbasis Permainan Dalam Meningkatkan Keterampilan Forehand Drive Mahasiswa. J Ilmu Keolahragaan. 2020; 19(1):54-62.

[4] Joyce B, Weil M. Models of Teaching. $2^{\text {nd }}$ Edition. New Jersey: Prentice Hall Inc; 1980.

[5] Siregar S. Perbedaan pengaruh metode mengajar dan kemampuan gerak terhadap keterampilan teknik dasar bermain bolavoli. Surakarta: Universitas Sebelas Maret; 2008.

[6] Arikunto S. Dasar-dasar Evaluasi Pendidikan. Jakarta: Bumi Aksara; 2009.

[7] Wang AI, Øfsdahl T, Mørch-storstein OK. Collaborative Learning Through Games Characteristics, Model, and Taxonomy. Challenges. 2009. 
[8] Gall MD, Gall JP, Borg WR. Educational Research: An Introduction. $8^{\text {th }}$ Edition. New York: Pearson Education; 2007. 